\title{
Adherence: a review of education, research, practice and policy in Spain
}

\author{
Narjis FIKRI-BENBRAHIM, Victoria GARCÍA-CÁRDENAS, Loreto SÁEZ-BENITO, \\ Miguel A. GASTELURRUTIA, María J. FAUS \\ Received (first version): 15-Jul-2009 Accepted: 8-Sep-2009
}

\begin{abstract}
${ }^{*}$
Aims: To describe medication adherence education, practice, research and policy efforts carried out by pharmacists in Spain in the last decade. Methods: A literature review using Medline and Embase was conducted covering the last ten years. Additional pharmaceutical bibliographic sources in Spain were consulted to retrieve articles of interest from the last decade. Articles were included if a pharmacist was involved and if medication adherence was measured or there was any direct or indirect pharmacist intervention in monitoring and/or improving adherence. Articles focusing on the development of tools for adherence assessment were collected. Pre- and post-graduate pharmacy training programs were also reviewed through the Spanish Ministry of Education and Science website. Information regarding policy issues was gathered from the Spanish and Autonomous Communities of Education and Health Ministries websites. Results: Pharmacists receive no specific training focused on adherence. There is no specific government policies for pharmacists in Spain related to medication adherence regardless of their practice setting. A total of 24 research studies met our inclusion criteria. Of these, 10 involved pharmacist intervention in monitoring and/or improving adherence and 14 assessed only adherence. Ten studies involved hospital pharmacists working in collaboration with another healthcare professional.

Conclusions: At present in Spain, the investigative role of the pharmacist is not well developed in the area of medication adherence. Adherence improvement services provided to patients by pharmacists are not implemented in a systematic
\end{abstract}

\footnotetext{
*Narjis FIKRI-BENBRAHIM. MSc(Pharm). Pharmaceutical Care Research Group, University of Granada. Granada (Spain).

Victoria GARCÍA-CÁRDENAS. MSc(Pharm).

Pharmaceutical Care Research Group, University of Granada. Granada (Spain).

Loreto SÁEZ-BENITO. MSc(Pharm). Pharmaceutical Care Research Group, University of Granada. Granada (Spain). Miguel A. GASTELURRUTIA. PhD. Pharmaceutical Care Research Group, University of Granada. Granada (Spain). María J. FAUS. PhD. Pharmaceutical Care Research Group, University of Granada. Granada (Spain).
}

Series editors:

Marie P. SCHNEIDER. PhD. Researcher and lecturer in Pharmacy Practice. Community Pharmacy, Dpt of ambulatory care and community medicine, University Hospital, Lausanne (Switzerland).

Parisa ASLANI. PhD. Senior Lecturer in Pharmacy Practice. Faculty of Pharmacy, University of Sydney (Australia). way. However, recent efforts to implement new initiatives in this area may provide the basis for offering new cognitive services aimed at improving patient adherence in the near future.

Keywords: Medication Adherence. Pharmacists. Spain.

\section{CUMPLIMIENTO: REVISIÓN DE LA EDUCACIÓN, INVESTIGACIÓN, PRÁCTICA Y POLÍTICA EN ESPAÑA}

\section{RESUMEN}

Objetivo: Describir la educación, práctica e investigación sobre adherencia farmacológica llevadas a cabo en la última década por farmacéuticos en España.

Métodos: Se hizo una revisión de la bibliografía de los últimos 10 años en Medline y Embase. Además, se consultaron otras fuentes bibliográficas farmacéuticas españolas para recuperar artículos de interés publicados en la última década. Los artículos se incluyeron si contaban con la participación de un farmacéutico y se medía la adherencia a la medicación, o si existía una intervención farmacéutica para monitorizar y/o mejorar la adherencia, de forma directa o indirecta. Se seleccionaron también los artículos que desarrollaban herramientas para la evaluación de la adherencia. También, se revisaron los programas de formación impartidos en pre y postgrado de farmacia. La evaluación de las políticas sobre este asunto se realizó analizando las páginas web de los Ministerios de Educación y de Sanidad y Política Social a nivel estatal, así como sus homólogos a nivel autonómico.

Resultados: Los farmacéuticos no reciben formación ninguna enfocada específicamente a la adherencia. Tampoco existe política ni práctica sanitaria obligatoria que deban seguir los farmacéuticos independientemente del ámbito sanitario donde ejerzan su profesión. Respecto a la investigación, se encontraron 24 estudios que cumplieron con los criterios de inclusión. De ellos, 10 trataban de alguna intervención farmacéutica para monitorizar y/o mejorar la adherencia y 14 sólo pretendían evaluar la adherencia. En diez de los estudios, participaron farmacéuticos hospitalarios en colaboración con otro profesional de la salud.

Conclusiones: Actualmente en España, la actividad investigadora del farmacéutico está poco desarrollada en el campo de la adherencia farmacológica. Los servicios que proporcionan los farmacéuticos a los pacientes para mejorar la 
adherencia no se implementan de forma generalizada. No obstante, parece ser que los esfuerzos que se están realizando últimamente para implantar nuevas iniciativas pueden constituir una base para que en un futuro cercano se comiencen a prestar servicios cognitivos encaminados a mejorar la adherencia de los pacientes.

Palabras clave: Adherencia a la medicación. Farmacéuticos. España.

\section{INTRODUCTION}

Non-adherence to drug therapy is a frequent and well known phenomenon in our environment and constitutes a major problem, particularly with chronic diseases, where it has a direct impact on patient health and is a principal cause of treatment failure. In fact, the World Health Organization (WHO) considers non-adherence to be a high priority public health issue. ${ }^{1}$ In addition to its health impact, the economic impact of non-adherence must be considered. ${ }^{2,3}$ Ineffective treatment resulting from undiagnosed non-adherence to therapy is quite frequent. ${ }^{4}$ Resultant unresolved symptoms may lead to additional diagnostic testing as well as dosage increases and/or unnecessary additional medications. Large amounts of time and money are invested in the search for new and more effective medications, while little attention is paid to whether or not patients are taking their medications, or taking them correctly.

The magnitude of non-adherence to drug therapy in Spain varies across studies depending on the type of treatment given and the measurement method applied. For example, a number of studies related to adherence by hypertensive patients to the recommendations given by their healthcare professionals have shown that non-adherence in hypertension varies between $40 \%$ and $71 \% .^{5-7}$ Thus it is critical to identify and monitor non-adherence as part of daily clinical practice.

There are direct and indirect methods for measuring adherence. ${ }^{8}$ Direct methods consist of measuring the medication, its metabolites, or other biochemical markers in bodily fluids. Though objective and specific, such methods are seldom used in routine practice due to their technical difficulty and high cost. Indirect methods are based on information provided by the patient via instruments such as clinical interviews, self-administered adherence questionnaires, pill counts, medication electronic monitoring systems (e.g. MEMS ${ }^{\mathrm{TM}}$ electronic monitors), and adherence to medication refills. These methods are useful in daily practice, although they may overestimate adherence. Patients are known to improve their adherence when they are being observed. ${ }^{8}$ Thus results must be interpreted with some caution. However, electronic monitoring and pill count have shown the best validity and are usually used as gold standards to calculate the validity of other indicators. ${ }^{8}$
Currently, several terms are used to describe when patients take their medication according to the instructions of healthcare professionals. Terms such as compliance or adherence to treatment are used in both healthcare practice and research. Differences notwithstanding, it is critical that this concept reflects patients' active participation in selecting and maintaining a therapeutic regimen ${ }^{9}$, as well as their understanding of the information given about their specific diseases and treatment. ${ }^{10}$ WHO states that adherence must be understood as a behavior in which the patient acts rationally on all recommendations provided by the team of professionals in the treatment of a disease. ${ }^{1}$

Understanding the reasons that drive a patient to nonadherence may help in meeting the stated therapeutic objectives. ${ }^{11}$ Non-adherence to treatment depends not only on the patient and the treatment characteristics, but also on factors related to the healthcare professionals treating the patient. Thus the problem must be addressed in a multidisciplinary basis.

In this context, community pharmacist is considered a professional both with the knowledge and the best availability to collaborate in ensuring correct use of medications and optimal patient adherence to treatment. A study on the effect of pharmacist intervention via written patient information on patients' adherence to antibiotic treatment showed an increase in adherence, and thus improved treatment results. ${ }^{12}$

These pharmacist patient support activities are part of the concept of pharmaceutical care, which is understood as the participation of the pharmacist in the assessment of clinical outcomes related to the use of drug therapy ${ }^{13,14}$, and more generally, the pharmacist's role in promoting and preserving health. In dispensing and over-the-counter (OTC) prescribing, the pharmacist must instruct the patient on the use of medications. Another patient-related task, which aims among others things at rationalizing and improving the use of medications, is medication review with follow-up. ${ }^{15-17}$ This activity includes the implementation of appropriate processes for preventing, monitoring and improving adherence to treatment in order to achieve healthcare outcomes.

This paper is a review that covers key aspects of the role of the pharmacist in Spain as it relates to adherence, specifically: Spanish national health policies in this area, the relevant training given to pharmacists in Spain, the research studies carried out and the services implemented to measure, monitor and improve adherence.

\section{METHODS}

\section{Education in medication adherence}

Presently, there are 18 Pharmacy Schools in Spain. Of these, nine offer the title of Graduate Pharmacist in compliance with the Bologna Declaration (whose aim is to regulate university degree programs across all of Europe). ${ }^{18}$ The remaining nine schools offer the title of Bachelor of Pharmacy, which is 
being phased out. All Pharmacy School programs in Spain were reviewed to identify any pre- or postgraduate courses related to medication adherence in their curricula. This was done by reviewing the Spanish Ministry of Education website. ${ }^{19}$ Both Graduate Pharmacist and Bachelor of Pharmacy degrees, as well as postgraduate educational courses, offered by Spanish Universities were reviewed. From this information, a search was performed to reveal which Universities offer pharmaceutical care courses that include any adherence related topic.

\section{Research, practice and policy in medication adherence}

A literature review was conducted to identify published literature on research projects or programs implemented in Spain that have focused on medication adherence in a pharmacy setting. The databases consulted were MEDLINE and EMBASE; both searches were limited to Spain in the last ten years.

The Medline search was performed on the basis of the following $\mathrm{MeSH}$ terms ("Patient Compliance", "Medication Adherence", "Pharmacists", "Pharmaceutical Services", "Pharmacy Administration", "Legislation, Pharmacy", "Societies, Pharmaceutical", "Insurance, Pharmaceutical Services"). In Embase, a number of search terms were used: "Patient Compliance", "Pharmacists", "Pharmacy", 'Health care organization", "Management", "Spain". The following professional journals were also manually searched to identify additional research projects and adherence programs implemented by pharmacists within Spain: Pharmaceutical Care, Offarm, Farmacia Profesional and Ars Pharmaceutica.

Articles retrieved in these searches were reviewed by three independent researchers to verify that they met the inclusion criteria. Namely, articles were included in the review if a pharmacist was involved and if medication adherence was measured or there was direct or indirect pharmacist intervention in monitoring and/or improving adherence. Articles focusing on the development of tools for adherence assessment were also selected.

To assess policy projects on medication adherence in Spain, Ministry of Education and Ministry of Health and Social Policy websites, as well as corresponding websites from every 17 Autonomous Community, were searched.

\section{RESULTS}

\section{Pharmacist education in adherence}

Pre-graduate education

None of the programs offered by the 18 universities had courses which focused specifically on adherence. However, a "pharmaceutical care" course was offered in seven universities. In particular, three of the schools that award the Graduate Pharmacist title had made this course mandatory while four others offer it as an elective course. These courses cover the three main services that, according to the Spanish Forum of Pharmaceutical Care ${ }^{15}$, constitute the philosophy of practice.

The Pharmacy White Paper [Libro Blanco $]^{20}$, published by the Spanish National Institute of Accreditation and Quality Evaluation (ANECA) [Agencia Nacional de Evaluación de la Calidad y Acreditación] calls for making pharmaceutical care a mandatory subject, and is the basis for a recent national regulation (CIN/2137/2008) delineating the competencies that pharmacy students must acquire. Key among these competencies are the following: the proficiency to identify and assess medication related problems, preparedness for participation in pharmacovigilance activities, and the ability to carry out the clinical and social roles of a pharmacist in accordance with the pharmaceutical care cycle.

\section{Post-graduate education}

A growing number of pharmaceutical care specialization courses are being offered by Spanish universities. While not exclusively focused on medication adherence, these courses teach the required skills to prepare pharmacists to implement adherence improvement strategies in any professional setting. Notably, students learn about how to deal with patients, with a focus on improving communication skills.

\section{Research in adherence to treatment}

\section{Search results and inclusion of studies}

Our Medline and Embase searches yielded 61 and 59 articles, respectively. Of these 120 articles, only 16 met all of the predefined inclusion criteria. In addition, we included eight articles found by manual search of Spanish pharmaceutical journals. Of the total group of 24 included articles, 10 involved pharmacist interventions to monitor or improve adherence ${ }^{12,21-29}$ while 14 were descriptive articles. $^{30-43}$

\section{Characteristics of the intervention studies}

Three studies were randomized clinical trials ${ }^{12,22,26}$, 4 were quasi-experimental studies without a control group $^{23,24,27,29}$, 2 were observational studies ${ }^{21,25}$ and another was ambispective. ${ }^{28}$ Three of the studies were conducted in hospital pharmacies ${ }^{21-23}$, six in community pharmacies ${ }^{12,24-28}$, and one in a primary care setting in collaboration with nearby community pharmacies. ${ }^{29}$ All of the studies were published in pharmacy journals except one that had been published in a medical journal. ${ }^{28}$ The articles were found among 10 journals, including eight national and two international journals.

Medication adherence was the primary parameter assessed in five of the studies ${ }^{12,25-28}$, and a secondary parameter in the remaining five studies. $^{21,22-24,29}$ In terms of disease type, six studies focused on chronic diseases: acquired immunodeficiency syndrome (AIDS) ${ }^{23}$, type II diabetes $^{26,29}$ hypertension 24,29 , dyslipidemia ${ }^{29}$, hepatitis $\mathrm{C}^{21}$, and cardiac insufficiency. ${ }^{22}$ Two studies dealt with antibiotic adherence ${ }^{12,28}$, and in two studies, no disease type was specified. ${ }^{25,27}$ 
Adherence monitoring was carried out by several methods or combinations of methods: clinical interview ${ }^{24,25}$ modified Morisky-Green questionnaire $^{23,26}$, Simplified Medication Adherence Scale, SMAE (Escala Simplificada de Adherencia a la Medicación) together with the Simplified Medication Adherence Questionnaire (SMAQ) and self-reported patient adherence ${ }^{23}$, a non-validated

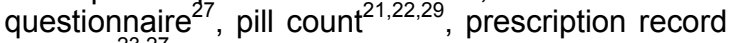
analysis $^{23,27}$, adherence to scheduled pharmacy visits $^{28}$, and Direct Observed Treatment (DOT). ${ }^{28}$

Four studies involved specifically designed educational interventions. ${ }^{12,21,22,28}$ Six studies involved Medication Review with Follow-up (five via the Dader Method ${ }^{24-27,29}$ and one with a different method $^{23}$ ). All of them utilized one of the abovementioned measurement methods or combination of methods. Seven of these articles showed significant adherence improvement after pharmacist intervention $^{12,22-27}$, although only three correlated pharmacist intervention with clinical parameters to demonstrate the effectiveness of the intervention ${ }^{23,24,26}$ (reduction of glycosylated hemoglobin, blood pressure and viral load). The key characteristics of these studies are summarized in Table 1.

\section{Characteristics of descriptive articles}

Of the 14 articles, six appeared in Spanish national publications $^{30-35}$ and eight in international publications. ${ }^{36-43}$ Nine articles were published in medical journals ${ }^{30,31,36-42}$ and five in pharmacy journals. ${ }^{32-35,43}$ In all studies, adherence was the primary stated objective. In terms of healthcare setting, 11 studies were carried out in hospital pharmacies ${ }^{31,32,35-43}$, two in community pharmacies $^{30,34}$ and one study in a hospital emergency department. ${ }^{33}$ The target population was primarily AIDS patients (11 of 14 studies). ${ }^{31,32,35-43}$ The 3 remaining studies involved hypertensive patients $^{34}$, pharmacy customers ${ }^{30}$, and emergency department patients without a specific disease focus. ${ }^{33}$ Hospital pharmacists were the primary healthcare professionals who measured adherence in collaboration with other healthcare professionals (in 10 of 14 studies): 8 with physicians ${ }^{31,33,35}$ $37,40,42,43$ and 2 with nurses. ${ }^{38,41}$ Two of the 4 remaining studies involved only hospital pharmacists $^{32,39}$ and the two others involved community pharmacists. ${ }^{30,34}$ The tools for measuring adherence were very diverse: structured interviews, prescription records from hospital pharmacies, specially designed questionnaires (e.g. Morisky-Green, modified Gao-Nao, Haynes-Sackett, and others not validated), pill count, medication refill, therapeutic drug monitoring, and/or selfreported adherence. In 10 of the studies, a combination of tools was used to measure adherence ${ }^{31,34-38,40-43}$, and in the remaining 4 , one tool was used exclusively. ${ }^{30,32,33,39}$ The key characteristics of these studies are summarized in Table 2.

\section{Pharmacy practice on adherence}

In the Spanish pharmacy environment, there is no established service offered specifically for adherence. However, reports studied for this review indicated that pharmacists do offer services that enable measurement, monitoring, and improvement of patient adherence to medication therapy. These services include pill-organizers ${ }^{44}$, Medication Review with Follow-up services ${ }^{23-27,29}$, and hospital protocol programs aimed at detecting adherence problems. ${ }^{45}$

National policies related to medication nonadherence

Spain is a European Union member with a population of 46 million. It has a semi-federal structure with 17 "Autonomous Community" states, which are further divided into 52 provinces. ${ }^{46}$ There are no specific government policies related to medication adherence currently in place in Spain. However, it is important to note that there are health policies at the professional level that address the role of the pharmacist in patient adherence to treatment. The recent health policy and consensus document on hypertension in Spain $^{47}$ is a good example of such a professional level policy. In this document, the various scientific societies and signatory organizations specify the need to develop pharmacy educational programs that raise patients' awareness of the impact of adherence on their health.

The recent consensus document published by a panel of experts from the Spanish Pharmaceutical Care Forum [Foro de Atención Farmacéutica] ${ }^{15}$ defines common terms and services and describes procedures for the practice of pharmaceutical care, including a proposal to Spanish software companies recommending implementation of certain agreed upon procedures in software programs for Spanish pharmacies. In this sense, a national strategy is emerging, at least in the area of pharmacy software, for the most important pharmaceutical care services, namely dispensing and OTC prescription, and medication review with follow-up. ${ }^{15}$ Although the outcomes of this development are not yet known, it is seen as a good opportunity for the further development of the pharmacist's role in patient adherence.

Nevertheless, at the governmental level, initiatives being carried out in some of the Autonomous Communities in Spain have shown improvement in addressing the issue of adherence by community pharmacies. ${ }^{49}$ For example, the broad adoption of electronic prescriptions enables pharmacists to know their patients' prescription and dispensing histories. This strategy could serve to strengthen the role of the pharmacist in improving adherence.

Among the strategies for improving adherence, three initiatives implemented so far in several Autonomous Communities deserve mention. ${ }^{28,50,51}$ In one case, a pilot collaborative effort is being carried out between local pharmacist professional associations and municipal home care services with the aim of improving medicine use of home-bound patients. The program consists of a dose administration aid, which is given to the patient at twice-monthly pharmacy visits and returned by the patient or caregiver at the next visit with any "pills not taken". Another national project, proposed in 2009 by Spanish health authorities, involves 
improvements in care for chronic and multiple-drug patients. Specific project activities include the contracting of qualified healthcare professionals for medication management, specifically pharmacists who can systematically review treatment effectiveness, promote rational drug use, and help patients adhere to their drug treatment. ${ }^{51}$ Finally, reimbursement of community pharmacist cognitive services has been established as part of a multidisciplinary care program focused on tuberculosis patients at risk for non-adherence. Pharmacists receive a standard fee per patient per month for directly supervising the delivery of tuberculosis medication, and for educating patients on adherence. ${ }^{28}$

\section{DISCUSSION}

Pre-graduate pharmacy education in Spain seems to be insufficient to achieve the skills required to manage adherence issues in the pharmacist's daily practice. With regard to the Spanish policies on adherence in the pharmacy setting, it appears there are also not sufficient efforts being implemented at the professional level to adequately enable implementation of new cognitive services and growth in the pharmacist's role. Such professional level efforts should be reinforced by government level strategies, as has been done in other countries $^{52-54}$, through the establishment of reimbursement to pharmacists and promotion of collaborative programs within the health care team.

It should be noted that the studies selected for this review revealed certain problem areas in research methodology related to adherence. One key problem is the reliability of adherence measurement methods. Many studies measured adherence with methods that were unreliable or not often recommended, such as the use of the MoriskyGreen test regardless of its validity for the specific disease, or the use of clinical interviews. Indeed, the researchers themselves when using a combination of methods revealed that there is little agreement between them. ${ }^{34-36,41}$ None of the studies reviewed used electronic monitors, the method recommended as the reference standard to measure the validity indicators for the other indirect methods. On the whole, few studies have monitored adherence via electronic monitors in Spain, likely because of the high cost of MEMS devices. MEMS have likewise not been used much in Australia according to a similar review conducted there. ${ }^{53}$

In terms of pharmacist involvement, more than half of included studies were carried out by hospital pharmacists. This highlights the low level of involvement of community pharmacists in adherence related activities, when in fact these pharmacists are in a unique position to promote medication adherence, being the last point of contact with the patient before beginning use of the medications. Strategies should be formulated to achieve greater involvement of the community pharmacist in promoting adherence.

Only four of the studies ${ }^{24-26,33}$ looked at the impact of improved adherence on health results, even while ethical standards for adherence research specify that any study which evaluates and improves adherence should not only contribute these isolated data points, but should also describe the clinical outcome benefits obtained. ${ }^{55}$ The only studies found to correlate adherence with health outcomes did not use the most valid designs and therefore could lead to erroneous conclusions. ${ }^{24,25,33}$

The above limitations should be taken into account in the design of future research studies. However, despite the possibility that these limitations may have introduced biases in prior studies, it is noteworthy that the results of most of the studies suggested that pharmacist intervention can improve patient adherence and/or patient's health status. ${ }^{12,21,22,24,26-28}$ In the experimental studies with control groups that were identified in our search, adherence in the experimental group patients was higher than in controls. ${ }^{12,22,26}$ These findings reinforce the statement that a pharmacist can play an important role in improving adherence when delivering information about medication, thereby helping patients to understand and remember prescribed dosages and educating them about the importance of following the recommendations of health care professionals. ${ }^{22,26}$

\section{CONCLUSIONS}

Presently, the investigative role of the pharmacist in Spain is not yet well developed in the area of medication adherence. Adherence improvement services provided by pharmacists to patients are not widely implemented in a systematic basis. However, recent efforts to implement new initiatives in this area may provide the basis for offering new cognitive services aimed at improving patient adherence in the near future. Pharmacists, regardless their practice setting, should be aware of the existence of a societal need for the rational use of medicines and, more specifically, for improving adherence to prescribed medical treatments.

\section{ACKNOWLEDGEMENTS}

Translation into English and the final editing has been performed by the scientific editing provider "Wright Science Right (WSR)"

\section{CONFLICT OF INTEREST}

None declared.

\section{References}

1. WHO. Adherence to long-term therapies. Evidence for actions. Geneve: World health

Organization;2004.http://www.who.int/chp/knowledge/publications/adherence_report/en/index.html (accessed 1-7-2009)

2. López Cabezas C, Falces Salvador C, Cubí Quadrada D, Arnau Bartés A, Ylla Boré M, Muro Perea N, et al. Randomized clinical trial of a postdischarge pharmaceutical care program vs. regular follow-up in patients with heart failure. Farm Hosp 2006;30:328-342. 
3. García MD, Orozco D, Gil V, Carratala C. Relación entre cumplimiento farmacológico y grado de control en pacientes con hipertensión, diabetes o dislipemia. Med Clin 2001;116(Supl.2):141-146.

4. Rodríguez-Marín J. Cumplimiento de regímenes terapéuticos y calidad asistencial. Rev Calidad Asistencial. 2006;21(5):255-263.

5. Gascón Cánovas JJ, Saturno Hernández PJ, Llor Esteban B; Grupo de Investigación del Proyecto EMCA sobre Evaluación y Mejora de la Adhesión Terapéutica en la Hipertensión. [Evaluation and improvement of therapy adherence of hypertensive patients]. Aten Primaria. 2001;28(9):615-619.

6. Márquez Contreras E, de la Figuera von Wichmann M, Roig Ponsa L, Naval Chamosa J. [Compliance with hypertension therapy in Spain, according to the views of family doctors. Complex project]. Aten Primaria. 2007;39(8):417-423.

7. Márquez Contreras E, Gil Guillén V, Casado Martínez JJ, Martel Claros N, De la Figuera von Wichmann M, Martín de Pablos JL, Atienza Martín F, Gros García T, Espinosa García J. [Analysis of studies published on hypertension treatment non-compliance in Spain between 1984 and 2005]. Aten Primaria. 2006;38:325-332.

8. Márquez Contreras E. Evaluación del incumplimiento en la práctica clínica. Hipertensión (Madr.) 2008;25(5):205-213

9. Wiederholt JB, Wiederholt PA. The patient: our teacher and friend. Am J Pharm Educ. 1997; 61; 415-423.

10. Murphy J, Coster G. Issues in patient compliance. Drugs. 1997;54:797-800.

11. Rigueira García Al. [Treatment compliance: what do we know about Spain?]. Aten Primaria. 2001;27(8):559-568.

12. Machuca M, Espejo J, Gutiérrez L, Machuca MP, Herrera J. La Información escrita del farmacéutico mejora el cumplimiento de la antibioterapia. Ars Pharm. 2003;44(2):141-157.

13. Grupo de Consenso. Documento de Consenso en Atención Farmacéutica. Ars Pharm. 2001;42: 223-243.

14. Herrera Carranza J. [Objectives of pharmaceutical care]. Aten Primaria. 2002;30(3):183-187.

15. Pharmaceutical Care Forum, Expert panel. Consensus Document, January 2008. Consejo General de Colegios Oficiales de Farmacéuticos, Madrid. ISBN 978-84-613-1219-1.

16. Pharmaceutical Care Research Group, University of Granada (Spain). Pharmacotherapy follow-up: The Dader method (3rd revision: 2005). Pharm Pract. 2006;4(1):44-53.

17. Sabater D, Silva-Castro MM, Faus MJ. Metodo Dader: Guia de Seguimiento Farmacoterapeutico. Granada: Universidad de Granada; 2007.

18. Gobierno de España. Ministerio de Educación. Oferta de Titulaciones. Tipo de Estudio: Grado $1^{\circ}$ y $2^{\circ}$ ciclo. Rama: Ciencias de la salud. Enseñanza: Grado en Farmacia.

https://www.educacion.es/ructweb/jsp/busquedaDo.do?opcionMenu=BusquedaSimple\&codTipoUniversidad=T\&nomTip oUniversidad=Todas\&codUniversidad=T\&nomUniversidad=Todas\&nomTitula=Grado\%20en\%20Farmacia\&codRama $=4$ 31005\&nomRama=Ciencias\%20de\%20la\%20Salud\&codAut=00\&codProv=00\&tipoEnsenanza=CICLO (accessed 1-72009).

19. Ministerio de Educación. Oferta de titulaciones: https//www.educacion.es/ructweb/jsp/compBdDo.do (accessed 1-72009).

20. Agencia Nacional de Evaluación de la Calidad y Acreditación. Libro blanco. Título de Grado en Farmacia. 2005. http://www.aneca.es/media/150368/libroblanco_farmacia_def.pdf (accessed 1-7-2009).

21. Marino EL, Alvarez-Rubio L, Miro S, Modamio P, Banos F, Lastra CF, Alberdi-Leniz A. Pharmacist intervention in treatment of patients with genotype 1 chronic hepatitis C. J Manag Care Pharm. 2009 Mar; 15(2):147-150

22. López C, Falces C, Cubí D, Arnau A, Ylla M, Muro N, Homs E. Ensayo clínico aleatorizado de un programa de atención farmacéutica al alta frente al seguimiento habitual en pacientes con insuficiencia cardiaca. Farm Hosp. 2006; 30:328342

23. Ventura JM, Alós M. Programa de Atención farmacéutica a pacientes con VIH con tratamiento antirretroviral: metodología y documentación. Farm Hosp. 2004;28(1):72-79.

24. Arias JL, Santamaría-López JM. Mejora de los resultados de la farmacoterapia de pacientes hipertensos en una farmacia comunitaria. Ars Pharm. 2008;49(1):13-24.

25. García-Jiménez E, Amariles P, Machuca M, Parras-Martín M, Espejo-Guerrero J, Faus MJ. Incumplimiento, problemas relacionados con los medicamentos y resultados negativos asociados a la medicación: causas y resultados en el seguimiento farmacoterapéutico. Ars Pharm. 2008;49(2):145-157.

26. Andrés NF, Fornos JA, Andrés JC. Valoración del conocimiento/cumplimiento en un programa de SFT en diabéticos tipo 2 en farmacia comunitaria: estudios aleatorizado. Pharm Care Esp 2007;9(1):2-9.

27. Rodríguez MA, Rodríguez A, García E. incumplimiento terapéutico en pacientes en seguimiento farmacoterapéutico mediante el método Dáder en dos farmacias rurales. Pharm Care Esp 2006;8(2):62-68.

28. Juan G, Lloret T, Perez C, Lopez P, Navarro R, Ramón M, Cortijo J, Morcillo EJ. Directly observed treatment for tuberculosis in pharmacies compared with self-administered therapy in Spain. Int J Tuberc Lung Dis. 2006;10(2):215221

29. Bofill C, Valenti MJ, Palmer JL, Rovira M, Nogareda F, Cimadevilla D, et al. Intervención sobre uso racional del medicamento: experiencia piloto en centros de atención primaria y las farmacias de su entorno. Pharm Care Esp. 2006; 8(5):209-217

30. Bueno Gómez M, Barrionuevo Sancho MD, Fikri Benbrahim N, García-Jiménez E. [Causes of non-compliance of patients who attend a community pharmacy in Granada]. Aten Primaria. 2008;40(2):101-106.

31. Martín MT, del Cacho E, López E, Codina C, Tuset M, de Lazzari E, Miró JM, Gatell JM, Ribas J. [Adverse side effects of antiretroviral therapy: relationship between patients' perception and adherence]. Med Clin (Barc). 2007;129(4):127133

32. Morillo Verdugo R, Abdel-Kader Martín L, Márquez Saavedra E, Martínez Alonso I, Artacho Criado S, Almeida González C, Miguel del Corral M. Análisis de las causas de suspensión del régimen antirretroviral simplificado abacavir, lamivudina y zidovudina. Farm Hosp. 2005;29(3):164-170. 
33. Baena MI, Fajardo P, Martínez-Olmos J, Martínez- Martínez F, Moreno P, Calleja MA, Luque FM, Sierra F, Parras M, Romero JM, Vargas J, López E, Fernández-Llimós F, Faus MJ. Cumplimiento, conocimiento y automedicación como factores asociados a los resultados clínicos negativos de la farmacoterapia. Ars Pharm. 2005; 46 (4): $365-381$.

34. Méndez Lora M, del Valle Gómez MO, López González ML, López González I. Descripción del cumplimiento farmacológico antihipertensivo y sus determinantes psicosociales. Pharm Care Esp. 2006, 8(5): $199-252$.

35. Ventura-Cerdá JM, Mínguez-Gallego C, Fernández-Villalba EM, Alós-Almiñana, Andrés-Soler J. Escala simplificada para detectar problemas de adherencia (ESPA) al tratamiento antirretroviral. Farm Hosp. 2006; 30(3): $171-176$.

36. Martín-Sánchez V, Ortega-Valín L, Pérez-Simón MR, Mostaza-Fernández JL, Ortiz de Urbina-González JJ, RodríguezMaría MM, Carro-Fernández JA, Cuevas-González MJ, Alcoba-Leza M, y Grupo de Trabajo sobre Adhesión a TARGA. [Factors predicting lack of adherence to highly active antiretroviral treatment]. Enferm Infecc Microbiol Clin. 2002; 20(10):491-497.

37. Martín J, Escobar I, Rubio R, Sabugal G, Cascón J, Pulido F. Study of the validity of a questionnaire to assess the adherence to therapy in patients infected by HIV. HIV Clinical Trials. 2001; 2(1):31-37.

38. Alcoba M, Cuevas MJ, Perez-Simon MR, Mostaza JL, Ortega L, Ortiz de Urbina J, Carro JA, Raya C, Abad M, Martin V; HAART Adherence Working Group for the Province of Leon, Spain. Assessment of adherence to triple antiretroviral treatment including indinavir: role of the determination of plasma levels of indinavir. J Acquir Immune Defic Syndr. 2003; 33(2):253-258.

39. García de Olalla P, Knobel H, Carmona A, Guelar A, López-Colomés JL, Caylà JA. Impact of adherence and highly active antiretroviral therapy on survival in HIV-infected patients. J Acquir Immune Defic Syndr. 2002;30(1):105-110.

40. Girón-González JA, López-Sánchez A, Elvira J, Perez E, Fernández-Gutiérrez C. Effect of patient adherence to antiretroviral therapy on CD4+ cell count, HIV-1 RNA, and serum concentrations of tumor necrosis factor and its soluble receptors. Eur J Clin Microbiol Infect Dis. 2000;19(11):852-858.

41. Codina C, Martínez M, Tuseta M, Cacho E, Martín MT, Miró JM, Mallolas J, Lazzari E, García F, Martínez E, Gatell JM y Ribas J. Comparison of three methods to calculate adherence in patients receiving antiretroviral treatment. Enferm Infecc Microbiol Clin 2002;20(10):484-490.

42. Cuevas González MJ, Valín LO, Pérez-Simón MD, Mostaza Fernández JL, Alcoba Leza M, Sánchez VM; the HAART Adherence Working Group of the Province of Léon, Spain. A Prospective Study of Adherence and Virologic Failure in HIV-Infected Patients: Role of a Single Determination of Plasma Levels of Antiretroviral Medications. J Int Assoc Physicians AIDS Care 2007; 6(4):245-250.

43. Escobar I, Campo M, Martín J, Fernández-Shaw, Pulido F, Rubio. Factors affecting patient adherence to highly active antiretroviral therapy. Ann Pharmacother 2003;37:775-781.

44. Segura MM, Llaves E, Baena MI, García E, Lamenca AG, López B. Educación Sanitaria y Medipack en el cumplimiento posológico de pacientes con hipertensión arterial y dislipemias. Seguim Farmacoter 2004;2(supl 1):35.

45. Ibarra O, Ortega V, Grupo VIH de la SEFH. Encuesta de la Atención Farmacéutica en el paciente con VIH en España. Farm Hosp 2008;32(3):170-177.

46. Gastelurrutia MA, Faus MJ, Fernández-Llimós F. Providing Patient Care in Community Pharmacies in Spain. Ann Pharmacother 2005;39:2105-2110.

47. Banegas JR, Jovell A, Abarca B, Aguilar Diosdado M, Aguilera L, Aranda P, Bertoméu V, Capilla P, Conthe P, De Alvaro F, Fernández-Pro A, Formiguera X, Frías J, Guerrero L, Llisterri JL, Lobos JM, Macías JF, Martín De Francisco AL, Millán J, Morales JC, Palomo V, Roca-Cusachs A, Román J, Sanchis C, Sarriá A, Segura J, De La Sierra A, Verde L, Zarco J, Ruilope LM. [Hypertension and health policy in Spain]. Med Clin (Barc) 2009;132(6):222-229.

48. Gastelurrutia MA. Spanish Consensus on Pharmaceutical Care. Pharmaceutical Care Forum. In: Conference Abstracts: Abstracts of the PCNE 7th Working Conference.2009. PP.18.

49. Plan Estratégico de Política Farmacéutica para el Sistema Nacional de Salud Español. Ministerio de Sanidad y Consumo. 2004. http://bscw.iesalbasit.es/pub/bscw.cgi/d102154/PLAN\%20ESTRATICO\%20DE\%20SANIDAD.pdf (accessed 1-7-2009).

50. Gastelurrutia MA, Larrañaga B, Garay A, Echeveste FA. Program to improve the use of medication by users of the Municipal Domiciliary Care Service in Gipuzkoa. In: Conference Abstracts: Abstracts of the PCNE 7th Working Conference. 2009. PP.17

51. [Ministerio de Sanidad y Política Social - Gabinete de Prensa - Notas de Prensa]: http://www.msps.es/gabinetePrensa/notaPrensa/ desarrolloNotaPrensa.jsp?id=1443 (accessed 1-7-2009).

52. Schneider MP, Krummenacher I, Figueiredo H, Marquis J, Bugnon O. Adherence: a review of education, research, practice and policy in Switzerland. Pharm Pract. 2009;7(2):63-73.

53. Aslani P, Krass I. Adherence: a review of education, research, practice and policy in Australia. Pharm Pract. 2009;7(1):1-10

54. Södergård B. Adherence to treatment: what is done in Sweden? Practice, education and research. Pharm Pract. 2008;6(4):171-177

55. Haynes RB, Yao X, Degani A, Kripalani S, Garg A, McDonald HP. Interventions to enhance medication adherence. Cochrane Database Syst Rev. 2008;(2):CD000011.

56. Comité de Consenso. Tercer Consenso de Granada sobre Problemas Relacionados con los Medicamentos (PRM) y Resultados Negativos asociados a la Medicación. Ars Pharm. 2007;48(1):5-17.

57. Baena MI, Calleja MA, Romero JM, Vargas J, Jiménez J, Faus MJ. The validation of a questionnaire for the identification of problems arising from the use of medicines by patients at a hospital emergency ward. Ars Pharm. 2001; 42:147-171.

58. Gao X, Nau DP. Congruence of three self-report measures of medication adherence among HIV patients. Ann Pharmacother. 2000;34(10):1117-1122. 


\begin{tabular}{|c|c|c|c|c|c|c|c|}
\hline \multirow{4}{*}{$\begin{array}{l}\text { Study Characteristics } \\
\text { Andrés NF et al. }{ }^{26} \\
\text { Design: randomized clinical trial } \\
\text { Objective: To carry out Medication Review with } \\
\text { Follow-up and individualized educational } \\
\text { interventions; to evaluate patients' knowledge and } \\
\text { medication adherence. } \\
\text { Duration: } 1 \text { year } \\
\text { Study Population: } 112 \text { patients ( } 56 \text { in the control } \\
\text { group and } 56 \text { in the intervention group) diagnosed } \\
\text { with type } 2 \text { diabetes. } \\
\text { Setting: Community pharmacy. }\end{array}$} & Description of Intervention & \multirow{4}{*}{\begin{tabular}{l}
\multicolumn{1}{c}{$\begin{array}{c}\text { Adherence } \\
\text { Assessment }\end{array}$} \\
Modified \\
Morisky-Green \\
questionnaire
\end{tabular}} & \multirow{4}{*}{$\begin{array}{l}\begin{array}{c}\text { Study Outcomes } \\
\text { Assessed }\end{array} \\
\text { - No. of errors in } \\
\text { medication/ } \\
\text { medication } \\
\text { adherence } \\
\text { - Level of } \mathrm{HbA}_{1 \mathrm{c}}\end{array}$} & \multicolumn{4}{|c|}{$\begin{array}{c}\text { Quantitative Results for Medication Adherence } \\
\text { and Health Results }\end{array}$} \\
\hline & \multirow{3}{*}{$\begin{array}{l}\text { - Medication Review with Follow-up } \\
\text { via the Dáder Method. } \\
\text { - Educational intervention specifically } \\
\text { designed for the study, both to } \\
\text { increase patient knowledge to } \\
\text { medications and to improve patient } \\
\text { medication adherence, which was } \\
\text { carried out in parallel to Medication } \\
\text { Review with Follow-up. }\end{array}$} & & & & Controls & $\begin{array}{c}\text { Inter- } \\
\text { vention }\end{array}$ & $p$-value \\
\hline & & & & $\begin{array}{r}\text { Adherence } \\
\text { failures (\%) }\end{array}$ & $0.6 \pm 0.9$ & $0.2 \pm 0.5$ & $<0.001$ \\
\hline & & & & $\begin{array}{c}\mathrm{HbA}_{1 \mathrm{c}} \\
\text { levels(mg/d } \\
\mathrm{L}) \\
\end{array}$ & $8.4 \pm 1.8$ & $7.9 \pm 1.7$ & $<0.001$ \\
\hline $\begin{array}{l}\text { Arias JL et al. }{ }^{24} \\
\text { Design: Quasi-experimental, no controls } \\
\text { Objective: Analyze and classify drug-related } \\
\text { problems (DRP) }{ }^{\mathrm{b}} \text { detected via Medication Review } \\
\text { with Follow-up. } \\
\text { Duration: } 5 \text { years } \\
\text { Study Population: } 36 \text { patients with diagnosed } \\
\text { Hypertension or elevated levels of blood pressure } \\
\text { (BP), meaning blood pressure levels higher than } \\
140 / 90 \text { mmHg without hypertension diagnosis. } \\
\text { Setting: Community pharmacy. }\end{array}$ & $\begin{array}{l}\text { - Medication Review with Follow-up } \\
\text { via the Dáder Method. } \\
\text { - Individualized educational } \\
\text { intervention to increase knowledge } \\
\text { about disease, treatment, diet and } \\
\text { hygiene measures and promote } \\
\text { medication adherence. }\end{array}$ & Clinical interview & $\begin{array}{l}\text { - DRP identified } \\
\text { and classified. }\end{array}$ & $\begin{array}{l}\text { Non-adherence } \\
\text { patients in follo } \\
\text { NOMs }^{\text {d }} \text {. } \\
\text { Medication adhe } \\
\text { after the pharma }\end{array}$ & $\begin{array}{l}\text { was the mos } \\
\text {-up, with a }\end{array}$ & $\begin{array}{l}\text { frequent DR } \\
\text { frequency of } \\
\text { hieved in ne } \\
\text { tion. }\end{array}$ & $\begin{array}{l}\text { Identified in } \\
26 \% \text { (of } 152 \\
\text { ly all patients }\end{array}$ \\
\hline \multirow{5}{*}{$\begin{array}{l}\text { Bofil C et al. } \\
\text { Design: Quasi-experimental, no controls } \\
\text { Objective: To conduct Medication Review with } \\
\text { Follow-up and measure of medication adherence } \\
\text { Duration: } 6 \text { months. } \\
\text { Study Population: } 280 \text { patients for Medication } \\
\text { Review with Follow-up, } 232 \text { for medication } \\
\text { adherence, with the following pathologies: arterial } \\
\text { hypertension, type } 2 \text { diabetes or dyslipidemia. } \\
\text { Setting: Primary care centers (for Medication } \\
\text { Review with Follow-up) and community pharmacies } \\
\text { (for medication adherence). }\end{array}$} & \multirow{5}{*}{$\begin{array}{l}\text { - Primary care Medication Review } \\
\text { with Follow-up phase: Pharmacist } \\
\text { recorded patient data, e.g. } \\
\text { medication-related and state of } \\
\text { health, and applied Dáder Method to } \\
\text { detect possible NOM. In addition, } \\
\text { periodic meetings were held with } \\
\text { primary care center doctors to } \\
\text { determine acceptability of } \\
\text { interventions. } \\
\text { - Pharmacy-setting adherence } \\
\text { phase: Medication adherence } \\
\text { assessment in all study patients and } \\
\text { intervention survey and health } \\
\text { intervention for nonadherant patients. }\end{array}$} & \multirow[t]{5}{*}{ Pill count ${ }^{\mathrm{e}}$. } & \multirow[t]{5}{*}{$\begin{array}{l}\text { - NOM }{ }^{\mathrm{d}} \text { identified } \\
\text { via Medication } \\
\text { Review with Follow- } \\
\text { up in primary care } \\
\text { center } \\
\text { - Percentage of } \\
\text { non- adherence }^{9}\end{array}$} & \multicolumn{4}{|c|}{$\begin{array}{l}\text { Of } 232 \text { patients, } 117(50.4 \%) \text { were nonadherent, and } 115 \\
(49.6 \%) \text { were adherent. } \\
\text { Reasons for nonadherence: forgetfulness ( } 76.1 \%) \text {, } \\
\text { symptom improvement }(15.4 \%) \text {, and adverse effects } \\
(8.5 \%) \text {. } \\
\text { Note: conditions not mutually exclusive. }\end{array}$} \\
\hline & & & & & \begin{tabular}{|c} 
Type 2 \\
Diabetes \\
$(\%)$
\end{tabular} & \begin{tabular}{|c|} 
Dys- \\
lipidemia \\
$(\%)$
\end{tabular} & $\begin{array}{c}\text { Hyper } \\
\text { tension } \\
(\%) \\
\end{array}$ \\
\hline & & & & Adherant & $45(56.6)$ & $62(45.9)$ & $105(51.0)$ \\
\hline & & & & Nonadherant & $36(44.4)$ & $73(54.1)$ & $101(49.0)$ \\
\hline & & & & Total & $81(34.9)$ & $\begin{array}{c}135 \\
(58.2)\end{array}$ & $206(88.8)$ \\
\hline
\end{tabular}




\begin{tabular}{|c|c|c|c|c|c|c|c|}
\hline Study Characteristics & Description of Intervention & $\begin{array}{l}\text { Adherence } \\
\text { Assessment }\end{array}$ & $\begin{array}{l}\text { Study Outcomes } \\
\text { Assessed }\end{array}$ & \multicolumn{4}{|c|}{$\begin{array}{l}\text { Quantitative Results for Medication Adherence } \\
\text { and Health Results }\end{array}$} \\
\hline $\begin{array}{l}\text { García-Jiménez E et al. }{ }^{25} \\
\text { Design: Observational cross-sectional study } \\
\text { Objective: Analysis of interventions with negative } \\
\text { results associated with medication (NOM) to } \\
\text { understand issues related to medication } \\
\text { nonadherence. } \\
\text { Duration: unknown } \\
\text { Study Population: } 660 \text { interventions in } 496 \\
\text { patients. } \\
\text { Setting: Community pharmacy. }\end{array}$ & $\begin{array}{l}\text { Medication Review with Follow-up via } \\
\text { the Dáder Method }\end{array}$ & Clinical interview & $\begin{array}{l}\text { NOMs due to } \\
\text { medication } \\
\text { nonadherence }\end{array}$ & \multicolumn{4}{|c|}{$\begin{array}{c}\text { Distribution of the } 660 \text { NOMs: } \\
\text { - } \quad \text { NOM associated with patient receiving the } \\
\text { necessary medication: } 196(29.7 \%) \text {. } \\
\text { - } \text { NOM associated with use of a medication the } \\
\text { patient does not need: } 24(3.6 \%) \text {. } \\
\text { - } \quad \text { OM associated with effectiveness level o } \\
\text { medication: } 407(61.7 \%) \text {. } \\
\text { - NOM associated with safety level o } \\
\text { medication: } 33(5.0 \%) .\end{array}$} \\
\hline $\begin{array}{l}\text { Juan G et al. }{ }^{28} \\
\text { Design: Ambispective (composed of an } \\
\text { observational prospective and an observational } \\
\text { retrospective) } \\
\text { Objective: To compare directly observed treatment } \\
\text { of tuberculosis in pharmacies (DOT, prospective } \\
\text { study) with self-administered treatment (SAT, } \\
\text { retrospective) in patients at risk of non-medication } \\
\text { adherence. } \\
\text { Duration: } 3 \text { years (retrospective) }+3 \text { years } \\
\text { (prospective) } \\
\text { Study Population: } 243 \text { tuberculosis (TB) patients at } \\
\text { risk for non-medication adherence (101 DOT and } \\
142 \text { SAT). } \\
\text { Setting: Community pharmacy. }\end{array}$ & $\begin{array}{l}\text { - In the DOT program, pharmacies } \\
\text { provided medication and social services } \\
\text { to outpatients previously diagnosed with } \\
\text { tuberculosis who were at risk for non- } \\
\text { medication adherence. } \\
\text { - Delivery of TB medications (with } \\
\text { social / health support and incentives) } \\
\text { carried out at the pharmacy by trained } \\
\text { pharmacist. Each patient visit to the } \\
\text { pharmacy served as an opportunity to } \\
\text { reinforce the importance of medication } \\
\text { adherence, by inquiring about the } \\
\text { occurrence of any drug-related events } \\
\text { and reminding the patient about } \\
\text { forthcoming pharmacy and hospital } \\
\text { appointments. }\end{array}$ & $\begin{array}{l}\text { Drug ingestion at } \\
\text { the pharmacy } \\
\text { Adherence to } \\
\text { medication refill. }\end{array}$ & $\begin{array}{l}\text { - Medication } \\
\text { adherence } \\
\text { - Detection of } \\
\text { drug-related } \\
\text { events; incremental } \\
\text { cost per patient } \\
\text { associated with } \\
\text { DOT } \\
\text { implementation } \\
\text { - Confirmation of } \\
\text { clinical cure by } \\
\text { bacteriology: } \\
\text { sputum culture of } \\
\text { Tuberculosis } \\
\text { Mycobacterium }\end{array}$ & \multicolumn{4}{|c|}{$\begin{array}{l}\text { Of } 101 \text { DOT patients, } 69(68 \%) \text { fully completed treatment } \\
\text { without incident, while } 32 \quad(32 \%) \text { missed some } \\
\text { appointments. Of these, } 12 \text { were tracked by the program } \\
\text { and did not interrupt treatment for more than two } \\
\text { consecutive doses, while the remaining } 20 \text { were lost to } \\
\text { follow-up. } \\
\text { Of the } 81 \text { (i.e., } 69 \quad 12 ; 80.2 \%) \text { patients who followed } \\
\text { DOT, } 76(75.2 \%) \text { completed treatment, two died of HIV } \\
\text { related disease and } 23 \text { were lost to follow-up } \\
\text { By contrast, in the SAT group, only } 30(27 \%) \text { patients } \\
\text { completed treatment, four died of TB-related disease and } \\
78 \text { were lost to follow-up, most because they dropped out } \\
\text { of treatment. }\end{array}$} \\
\hline \multirow{9}{*}{$\begin{array}{l}\text { López C et al. }{ }^{22} \\
\text { Design: Randomized clinical trial } \\
\text { Objective: To evaluate efficacy of multifactorial } \\
\text { educational intervention in patients with cardiac } \\
\text { insufficiency. } \\
\text { Duration: } 1 \text { year } \\
\text { Study Population: } 134 \text { patients ( } 67 \text { in each group) } \\
\text { hospitalized with cardiac insufficiency. } \\
\text { Setting: Hospital pharmacy. }\end{array}$} & \multirow{9}{*}{$\begin{array}{l}\text { - Evaluated medication adherence. } \\
\text { - Individualized educational } \\
\text { intervention focused on: } \\
\text { - Disease information } \\
\text { - Diet education } \\
\text { - Medication treatment } \\
\text { information }\end{array}$} & \multirow[t]{9}{*}{ Pill count $^{f}$} & \multirow{9}{*}{$\begin{array}{l}\text { - Number of re- } \\
\text { hospitalized } \\
\text { patients. } \\
\text { - Medication } \\
\text { adherence. } \\
\text { - Quality of life } \\
\text { - Patient satisfied } \\
\text { with intervention } \\
\text { received. }\end{array}$} & \multicolumn{4}{|c|}{ Number of post-intervention adherent patients : } \\
\hline & & & & 2 months. & $\begin{array}{c}\text { Control } \\
26 \\
(60.5 \%)\end{array}$ & $\begin{array}{c}\text { Intervention } \\
45(88.2 \%)\end{array}$ & $\frac{\text { p-value }}{0.002}$ \\
\hline & & & & 6 months. & $\begin{array}{c}20 \\
(69.0 \%) \\
\end{array}$ & $41(91.1 \%)$ & 0.015 \\
\hline & & & & 12 months. & $\begin{array}{c}17 \\
(73.9 \%) \\
\end{array}$ & $34(85.0 \%)$ & $\begin{array}{c}\text { Not } \\
\text { significant } \\
\end{array}$ \\
\hline & & & & \multicolumn{4}{|c|}{$\begin{array}{l}\text { Number of re-hospitalizations decreased in patients who } \\
\text { received the intervention compared to patients who didn't } \\
\text { receive it: }\end{array}$} \\
\hline & & & & & Control & Intervention & p-value \\
\hline & & & & 2 months. & $\begin{array}{c}16 \\
(25 \%) \\
\end{array}$ & $8(11.4 \%)$ & 0.041 \\
\hline & & & & 6 months. & $\begin{array}{c}27 \\
(42.2 \%) \\
\end{array}$ & $17(24.3 \%)$ & 0.028 \\
\hline & & & & $\begin{array}{c}12 \\
\text { months. }\end{array}$ & $\begin{array}{c}31 \\
(48.4 \%) \\
\end{array}$ & $23(32.9 \%)$ & $\begin{array}{c}\text { Not } \\
\text { significant }\end{array}$ \\
\hline
\end{tabular}




\begin{tabular}{|c|c|c|c|c|}
\hline Study Characteristics & Description of Intervention & $\begin{array}{c}\text { Adherence } \\
\text { Assessment }\end{array}$ & $\begin{array}{l}\text { Study Outcomes } \\
\text { Assessed }\end{array}$ & $\begin{array}{l}\text { Quantitative Results for Medication Adherence } \\
\text { and Health Results }\end{array}$ \\
\hline $\begin{array}{l}\text { Machuca M et al. }{ }^{12} \\
\text { Design: Randomized clinical trial } \\
\text { Objective: Determine the effect of written } \\
\text { information on patient medication adherence to } \\
\text { antibiotic treatment and analyze possible causes for } \\
\text { non-medication adherence. } \\
\text { Duration: } 2 \text { months. } \\
\text { Study Population: } 214 \text { patients (105 intervention, } \\
109 \text { control) } \\
\text { Setting: Community pharmacy }\end{array}$ & $\begin{array}{l}\text { - Both control and intervention } \\
\text { groups: Provide treatment information } \\
\text { such as dosage and treatment } \\
\text { duration, as well as life-style. } \\
\text { - Intervention group only: reinforce } \\
\text { the information transmitted in writing. }\end{array}$ & $\begin{array}{l}\text { Clinical interview } \\
\text { (adherence was } \\
\text { defined as the } \\
\text { patient taking } \\
100 \% \text { of the } \\
\text { doses prescribed } \\
\text { by the doctor) }\end{array}$ & $\begin{array}{l}\text { - Medication } \\
\text { adherence. } \\
\text { - Causes for } \\
\text { nonadherence. }\end{array}$ & $\begin{array}{l}\text { Adherent subjects in control group: } 51(46 \%) . \\
\text { Adherent subjects in intervention group: } 64(61 \%) . \\
\text { Causes for non-medication adherence (in } 99 \\
\text { nonadherent subjects): } \\
\text { - } \quad \text { Dropped out of treatment: } 31 \\
\text { - Inadequate dosage: } 56 \\
\text { - } \quad \text { Adverse reaction: } 7 \\
-\quad \text { Other: } 5\end{array}$ \\
\hline $\begin{array}{l}\text { Marino EL et al. }{ }^{20} \\
\text { Design: Prospective, open-label study } \\
\text { Objective: To describe pharmacist intervention } \\
\text { results in optimizing response in treatment-naïve } \\
\text { patients with chronic hepatitis } C \text { virus infection. } \\
\text { Duration: } 48 \text { weeks } 42 \text { months. } \\
\text { Study Population: } 50 \text { patients with chronic } \\
\text { Hepatitis C virus infection. } \\
\text { Setting: Hospital pharmacy. }\end{array}$ & $\begin{array}{l}\text { - Pharmacist provided patients } \\
\text { medication therapy management } \\
\text { (including adherence), education and } \\
\text { support, to make them active } \\
\text { participants in their therapy. } \\
\text { - If required, patients were given } \\
\text { follow-up visits with the pharmacist to } \\
\text { monitor patients closely and assess } \\
\text { whether strategies were effectively } \\
\text { promoting medication adherence. }\end{array}$ & $\begin{array}{l}\text { - Pill count }{ }^{\mathrm{a}} \text {. } \\
\text { - Adherence } \\
\text { monitored at } \\
\text { scheduled visits } \\
\text { at wks } 4,8,14, \\
20,24,32,40, \\
\text { and 48 by } \\
\text { inspecting pill } \\
\text { boxes. }\end{array}$ & $\begin{array}{l}\text { - Medication } \\
\text { adherence } \\
\text { - Early viral } \\
\text { response } \\
\text { - Sustained viral } \\
\text { response } \\
\text { - Adverse effects }\end{array}$ & $\begin{array}{l}\text { The mean medication adherence rate was } 85.7 \% \text { in the } \\
\text { overall sample and } 95.5 \% \text { in patients who achieved } \\
\text { sustained viral response. } \\
\text { The rate of early viral response was } 68.0 \%(n=34) \text {. Of } \\
\text { the patients who had an early viral response, } 70.6 \% \text { ( } n= \\
24 \text { ) achieved a sustained viral response. }\end{array}$ \\
\hline $\begin{array}{l}\text { Rodríguez MA et al. }{ }^{2 \prime} \\
\text { Design: Quasi-experimental, no controls } \\
\text { Objective: To measure the degree of } \\
\text { nonadherence in Medication Review with Follow-up } \\
\text { patients, to determine types of NOM due to } \\
\text { medicine non-adherence, to identify types of non } \\
\text { adherence. } \\
\text { Duration: not specified } \\
\text { Study Population: } 89 \text { Medication Reviews with } \\
\text { Follow-up } \\
\text { Setting: Community pharmacy. }\end{array}$ & $\begin{array}{l}\text { Medication Review with Follow-up via } \\
\text { the Dáder Method }\end{array}$ & $\begin{array}{l}\text { - Clinical } \\
\text { interview } \\
\text { - Non- validated } \\
\text { questionnaire } \\
\text { - Pharmacy } \\
\text { records. }\end{array}$ & $\begin{array}{l}\text { - Levels and types } \\
\text { of non-medication } \\
\text { adherence } \\
\text { - Types of NOM }{ }^{d} \\
\text { due to medication } \\
\text { nonadherence }\end{array}$ & $\begin{array}{l}275 \text { NOM interventions, of which } 43(16 \%) \text { were due to } \\
\text { medication nonadherence: } \\
-\quad \text { Necessity NOM: } 17(39.6 \%) \\
-\quad \text { Non-necessity NOM: } 1(2.3 \%) \\
-\quad \text { Effectiveness NOM: } 22(51.2 \%) \\
-\quad \text { Safety NOM: } 3(7.0 \%) \\
\text { The most common reasons for medication nonadherence } \\
\text { was patient's lack of confidence in the treatment, present } \\
\text { in } 8 \text { cases (18.6\%); } 95.3 \% \text { of the interventions were } \\
\text { acceptable to the doctor and } 74.4 \% \text { of the health issues } \\
\text { were resolved. }\end{array}$ \\
\hline $\begin{array}{l}\text { Ventura JM et al. }{ }^{23} \\
\text { Design: Quasi-experimental, no controls } \\
\text { Objective: Describe a Pharmacy Care program. } \\
\text { Duration: } 1 \text { year } \\
\text { Study Population: } 355 \text { HIV patients. } \\
\text { Setting: Hospital pharmacy. }\end{array}$ & $\begin{array}{l}\text { Medication Review with Follow-up } \\
\text { using their own methodology. }\end{array}$ & $\begin{array}{l}\text { - } S M A E^{h} \text { scale } \\
\text { - Prescription } \\
\text { records } \\
\text { - Non } \\
\text { adherent } \\
\text { patients: } \\
\text {-SMAQ } \\
\text {-Modified } \\
\text { Morisky-Green } \\
\text { test } \\
\text { - Self-reported } \\
\text { medication } \\
\text { adherence. } \\
\end{array}$ & $\begin{array}{l}\text { - DRPs } \\
\text { - Medication } \\
\text { nonadherence } \\
\text { - Viral Load } \\
\text { - CD4 T- } \\
\text { Lymphocytes }\end{array}$ & $\begin{array}{l}\text { The most frequent DRPs were due to medication } \\
\text { adherence problems ( } 30 \% \text { of patients). } \\
\text { Significant differences were found in viral loads between } \\
\text { the } 1 \text { st and } 5 \text { th visit. No direct relationship between DRPs } \\
\text { and adherence was found, although increasing the } \\
\text { number of visits between the first and the fifth visit did } \\
\text { significantly affect viral load. }\end{array}$ \\
\hline
\end{tabular}




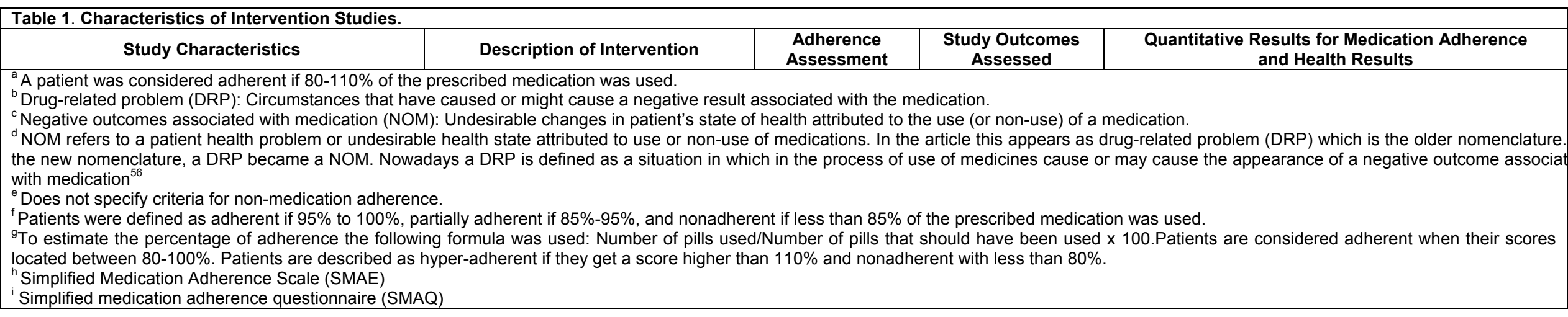

\begin{tabular}{|c|c|c|c|c|c|}
\hline \multirow{10}{*}{$\begin{array}{l}\text { Study Characteristics } \\
\text { Alcoba et al. } \\
\text { Design: Cross-sectional study. } \\
\text { Setting: HIV outpatient clinics. } \\
\text { Study Population: HIV-positive patients treated with } \\
\text { Indinavir } \\
\text { Number of Subjects at Inclusion: } 106 \\
\text { Objective: To explore the contribution of Indinavir } \\
\text { plasma levels for evaluating self-reported adherence } \\
\text { and compare it to hospital pharmacy drug records. }\end{array}$} & \multirow{10}{*}{$\begin{array}{l}\text { Adherence Measurement Methods } \\
\text { - Clinical interview with a nurse: Doses missed during the } 4 \text { days } \\
\text { before the visit. Patients were considered nonadherent if they had } \\
\text { taken }<90 \% \text { of prescribed doses of at least one drug. } \\
\text { - Adherence to medication refill: Delay in collection of drugs at the } \\
\text { pharmacy. Patients were considered nonadherent when they reached a } \\
\text { cumulative delay of more than } 9 \text { days. } \\
\text { - Indinavir levels: Non-adherence was determined when plasma levels } \\
\text { were undetectable. }\end{array}$} & \multicolumn{4}{|c|}{ Study Outcomes } \\
\hline & & \multirow{2}{*}{\multicolumn{2}{|c|}{ Total non-adherence }} & \multirow{2}{*}{$\begin{array}{r}\mathbf{N} / 106(\%) \\
53(50.0 \%)\end{array}$} & \multirow{2}{*}{$\begin{array}{c}95 \% \mathrm{Cl} \\
37.7- \\
56.7\end{array}$} \\
\hline & & & & & \\
\hline & & \multicolumn{2}{|c|}{ 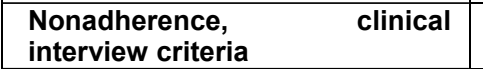 } & $23(21.7 \%)$ & $\begin{array}{l}0.1 \\
13.9- \\
29.5\end{array}$ \\
\hline & & \multicolumn{2}{|c|}{$\begin{array}{l}\text { Nonadherence, medication refill } \\
\text { criteria }\end{array}$} & $45(42.5 \%)$ & $\begin{array}{l}3.0- \\
51.9\end{array}$ \\
\hline & & \multicolumn{2}{|c|}{$\begin{array}{l}\text { Nonadherence, undetectable } \\
\text { Indinavir levels criteria }\end{array}$} & $65(61.3 \%)$ & $\begin{array}{l}52.0- \\
70.6\end{array}$ \\
\hline & & \multicolumn{4}{|c|}{$\begin{array}{l}\text { Correlation of medication adherence measures with plasma } \\
\text { levels }\end{array}$} \\
\hline & & \multirow{2}{*}{\multicolumn{2}{|c|}{ Clinical interview }} & OR & $95 \% \mathrm{Cl}$ \\
\hline & & & & 1.77 & $0.5-5.9$ \\
\hline & & \multicolumn{2}{|l|}{ Medication refill } & 8.01 & $\begin{array}{l}2.9- \\
22.0\end{array}$ \\
\hline \multirow{5}{*}{$\begin{array}{l}\text { Baena Ml et al. }{ }^{33} \\
\text { Design: Observational cross-sectional study. } \\
\text { Setting: Hospital Urgent Care Service, } \\
\text { Study Population: Patients attending a Hospital } \\
\text { emergency unit. } \\
\text { Number of Subjects at Inclusion: } 2556 \\
\text { Objective: Determine the proportion of negative } \\
\text { clinical results associated with medications (NOM) } \\
\text { which are related to non-adherence or to the level of } \\
\text { patients' knowledge about their drug therapy. }\end{array}$} & \multirow[t]{5}{*}{$\begin{array}{l}\text { - Validated adherence questionnaire (not specified in the paper) } \\
\text { - Description of health problems obtained from patient clinical } \\
\text { history. }\end{array}$} & \multicolumn{4}{|c|}{$\begin{array}{l}\text { Percentage of patient with a NOM, in relation to the adherence or } \\
\text { non-adherence to medication. Patients were classified in three } \\
\text { categories: nonadherent, partially adherent and adherent. } \\
\text { Subjects (\%) }\end{array}$} \\
\hline & & & $\begin{array}{c}\text { Nonadhere } \\
\text { nt }\end{array}$ & $\begin{array}{c}\text { Partially } \\
\text { adheren } \\
t\end{array}$ & $\underset{t}{\operatorname{adheren}}$ \\
\hline & & Necessity NOM & \multirow{2}{*}{$55.9 \%$} & $15.0 \%$ & $29.1 \%$ \\
\hline & & Effectiveness NOM & & $14.0 \%$ & $85.1 \%$ \\
\hline & & Safety NOM & $\begin{array}{ll}0.9 \% \\
3.1 \%\end{array}$ & $12.5 \%$ & $84.4 \%$ \\
\hline
\end{tabular}




\begin{tabular}{|c|c|c|c|c|}
\hline $\begin{array}{l}\text { Study Characteristics } \\
\end{array}$ & $\begin{array}{c}\text { Adherence Measurement Methods } \\
\end{array}$ & \multicolumn{3}{|c|}{ Study Outcomes } \\
\hline $\begin{array}{l}\text { Bueno Gómez M et al. } \\
\text { Design: Observational cross-sectional study. } \\
\text { Setting: Community pharmacy. } \\
\text { Study Population: Any patient coming in the } \\
\text { pharmacy to get medicines.. } \\
\text { Number of Subjects at Inclusion: } 139 \\
\text { Objective: Measure adherence and investigate } \\
\text { causes. }\end{array}$ & $\begin{array}{l}\text { - Morisky-Green questionnaire. } \\
\text { - A second non-validated questionnaire was given to nonadherent } \\
\text { patients to determine possible causes for non-adherence. }\end{array}$ & \multicolumn{3}{|c|}{$\begin{array}{l}108 \text { patients }(78 \%) \text { were nonadherent. } \\
\text { The primary cause for nonadherence was patient's perceived } \\
\text { improvement in health in } 87 \text { patients }(81 \%) \text {. }\end{array}$} \\
\hline $\begin{array}{l}\text { Codina et al. }{ }^{41} \\
\text { Design: Prospective observational study } \\
\text { Setting: Outpatient clinic. } \\
\text { Study Population: HIV Ambulatory patients treated } \\
\text { with HAART. } \\
\text { Duration: } 12 \text { months. } \\
\text { Objective: To compare three methods for assessing } \\
\text { medication adherence } \\
\text { Number of Subjects at Inclusion: } 69\end{array}$ & $\begin{array}{l}\text { - Pill count: Adherence was calculated according to: [dispensed } \\
\text { medication - returned medication]/[(return date - dispensing date) } \times \\
\text { number of pills/day] } \times 100 \\
\text { - Clinical interview: Questionnaire combining Morisky-Green } \\
\text { instrument with other questions. Adherence was quantified based on } \\
\text { the number of days in the last month in which the patient had omitted } \\
\text { a dose. } \\
\text { - Adherence to medication refill: Patients were considered } \\
\text { nonadherent if they failed to keep pharmacy appointments. }\end{array}$ & \multicolumn{3}{|c|}{$\begin{array}{l}\text { Adherence by each method: } \\
\text {. Pill count: } 72.5 \% \\
\text {. Clinical Interview: } 85.5 \% \\
\text {. Medication refill: } 81.2 \%\end{array}$} \\
\hline \multirow{4}{*}{$\begin{array}{l}\text { Cuevas González et al. } \\
\text { Design: Prospective cohort study } \\
\text { Setting: Outpatient clinic. } \\
\text { Study Population: HIV-infected patients treated with } \\
\text { Indinavir } \\
\text { Number of Subjects at Inclusion: } 112 \\
\text { Duration: } 24 \text { months. } \\
\text { Objective: To explore the contribution of a single } \\
\text { determination of plasma levels for measuring } \\
\text { adherence as a means of predicting virologic failure. }\end{array}$} & $\begin{array}{l}\text { - Questionnaires: Doses missed during the } 4 \text { days before a visit. } \\
\text { Patients were considered nonadherent if they took }<90 \% \text { of } \\
\text { prescribed doses of at least one drug. } \\
\text { - Adherence to medication refill: Information from the hospital } \\
\text { pharmacy prescription database. Patients were identified as }\end{array}$ & & $\begin{array}{l}\text { Virologic } \\
\text { failure } \\
\text { Adjusted OR } \\
{[95 \% \mathrm{Cl}]}\end{array}$ & $\begin{array}{l}\text { Area under the } \\
\text { curve predicting } \\
\text { virologic failure } \\
{\left[\begin{array}{l}{[95 \% \mathrm{Cl}]} \\
\end{array}\right.}\end{array}$ \\
\hline & $\begin{array}{l}\text { nonadherent if they had cumulated a delay of }<9 \text { days in collecting } \\
\text { their medication during the previous } 3 \text { months. }\end{array}$ & $\begin{array}{l}\text { Questionnaire } \\
\text { s }\end{array}$ & $\begin{array}{c}2.55[1.64- \\
3.94]\end{array}$ & $\begin{array}{l}0.629[0.503- \\
0.755]\end{array}$ \\
\hline & $\begin{array}{l}\text { - Plasma levels: patients were nonadherent if plasma levels of } \\
\text { Indinavir were undetectable. }\end{array}$ & $\begin{array}{l}\text { Medication } \\
\text { refills }\end{array}$ & $\begin{array}{l}1.76[1.13- \\
2.75]\end{array}$ & $\begin{array}{l}0.672[0.552- \\
0.791]\end{array}$ \\
\hline & & Plasma levels & $\begin{array}{l}1.55[0.97- \\
2.47]\end{array}$ & $\begin{array}{l}0.602[0.468- \\
0.718]\end{array}$ \\
\hline $\begin{array}{l}\text { Escobar et al. }{ }^{43} \\
\text { Design: Cross-sectional study. } \\
\text { Setting: HIV outpatient clinics. } \\
\text { Study Population: Ambulatory HIV patients treated } \\
\text { with highly active antiretroviral therapy (HAART) } \\
\text { Number of Subjects at Inclusion: } 357 \\
\text { Objective: To determine the variables related to } \\
\text { HAART adherence. }\end{array}$ & $\begin{array}{l}\text { - Medication refill: Correlation of plasma levels of every } \\
\text { antiretroviral drug with the number of dosage forms dispensed by the } \\
\text { pharmacy department and the dispensing interval. A subject was } \\
\text { defined as adherent if the percentage of dispensed dosage forms was } \\
<95 \% \text { of the total prescribed. } \\
\text { - Variables measured: anxiety, recreational drugs and alcohol } \\
\text { consumption, number of drugs prescribed. }\end{array}$ & \multicolumn{3}{|c|}{$\begin{array}{l}\text { Adherent subjects: } 52 \%[95 \% \mathrm{Cl} 46.0: 57.9] \\
\text { Variables related to non-adherence }(\mathrm{p}<0.005) \text { : } \\
\text {. Score on the anxiety trait test } 75 \% \text { greater than that of the } \\
\text { general population. } \\
\text {. Recreational drugs or alcohol consumption. } \\
\text {. Number of drugs prescribed. }\end{array}$} \\
\hline $\begin{array}{l}\text { García de Olalla et al. } \\
\text { Design: Cohort study. } \\
\text { Setting: Hospital. } \\
\text { Study Population: HIV-infected patients } \\
\text { Duration: } 9 \text { years } \\
\text { Number of Subjects at Inclusion: } 1219 \\
\text { Objective: To assess the effect of antiretroviral } \\
\text { therapy adherence on survival in HIV-infected } \\
\text { patients. }\end{array}$ & $\begin{array}{l}\text { - Self Report: Doses missed in the month before the visit. Patients } \\
\text { were considered nonadherent if they declared that they took }<90 \% \text { of } \\
\text { the total doses of antiretroviral drug(s) prescribed. } \\
\text { - Medication refill at the pharmacy: Patients were considered } \\
\text { nonadherent if they failed to keep pharmacy appointments. }\end{array}$ & \multicolumn{3}{|c|}{$\begin{array}{l}\text { 3-year survival rates for adherent and non-adherent patients }(p= \\
0.003) \text { : } \\
\text { Adherent subjects: } 81 \% ;[95 \% \mathrm{Cl} 80: 84.8] \\
\text {. Nonadherent subjects: } 73 \% ;[95 \% \mathrm{Cl} 66.3: 78.4]\end{array}$} \\
\hline
\end{tabular}




\begin{tabular}{|c|c|c|c|c|c|c|c|}
\hline \multirow{7}{*}{$\begin{array}{l}\text { Girón-González et al. }{ }^{40} \\
\text { Design: Prospective observational study } \\
\text { Setting: Outpatient clinic in a tertiary care hospital. } \\
\text { Study Population: HIV-infected patients treated with } \\
\text { antiretroviral therapy (zidovudine plus zalcitabine [N = } \\
\text { 55] or zidovudine plus zalcitabine plus saquinavir [N = } \\
\text { 32]). } \\
\text { Number of Subjects at Inclusion: } 87 \\
\text { Duration: } 12 \text { months. } \\
\text { Objective: To determine non-adherence to HAART } \\
\text { over time and describe its effects on clinical } \\
\text { outcomes. }\end{array}$} & & \multicolumn{6}{|c|}{ Study Outcomes } \\
\hline & \multirow{6}{*}{$\begin{array}{l}\text { - Patient self-reporting: Patients were considered nonadherent if they } \\
\text { took }<80 \% \text { of their prescribed zidovudine in the month before the visit. } \\
\text { - Medication refill at the pharmacy: Patients were considered } \\
\text { nonadherent if they failed to keep pharmacy appointments. } \\
\text { - Changes in mean corpuscular volume: Patients were considered as } \\
\text { adherent if the mean volume was }>97 \mathrm{~mm}^{3} \text { or the increase was }>18 \\
\mathrm{~mm}^{3} \text { above the baseline mean volume. }\end{array}$} & \multicolumn{6}{|c|}{$\begin{array}{l}\text { Occurrence of opportunistic events: occurrence of opportunistic } \\
\text { events: }\end{array}$} \\
\hline & & & \multicolumn{5}{|c|}{ Adherant patients N (\%) } \\
\hline & & & $\begin{array}{c}3 \\
\text { months. }\end{array}$ & & \multicolumn{2}{|c|}{$\begin{array}{c}9 \\
\text { months. }\end{array}$} & $\begin{array}{c}12 \\
\text { months. }\end{array}$ \\
\hline & & $\begin{array}{l}\text { Double- } \\
\text { therapy }\end{array}$ & \multirow{2}{*}{\begin{tabular}{c|c}
30 \\
$(54.5 \%)$ \\
17 \\
$(53.1 \%)$ \\
\end{tabular}} & \multicolumn{2}{|c|}{$\begin{array}{c}27 \\
(49.0 \%)\end{array}$} & $27(49.0 \%)$ & $27(49.0 \%)$ \\
\hline & & $\begin{array}{l}\begin{array}{l}\text { Triple- } \\
\text { therapy }\end{array} \\
\end{array}$ & & \multicolumn{2}{|c|}{\begin{tabular}{c|c}
12 \\
$(37.5 \%)$
\end{tabular}} & $12(37.5 \%)$ & $12(37.5 \%)$ \\
\hline & & \multicolumn{6}{|c|}{$\begin{array}{l}\text { Double-therapy group: } 6(31.6 \%) \text { non-adherent patients and } 0 \\
\text { adherent patients had at least one opportunistic event. The } \\
\text { difference between both groups was statistically significant. } \\
\text { Triple-therapy group: } 4 \text { ( } 16 \%) \text { non-adherent patients and } 0 \\
\text { adherent patients had at least one opportunistic event. The } \\
\text { difference between both groups was not statistically significant. }\end{array}$} \\
\hline \multirow{6}{*}{$\begin{array}{l}\text { Martín J et al. }{ }^{37} \\
\text { Design: Cross-sectional study. } \\
\text { Setting: Hospital. } \\
\text { Study Population: HIV-infected patients. } \\
\text { Number of Subjects at Inclusion: } 242 \\
\text { Objective: To examine the validity of a questionnaire } \\
\text { for detecting non-adherence in HIV-infected patients } \\
\text { under antiretroviral treatment. }\end{array}$} & \multirow[t]{6}{*}{ Non-validated questionnaire and pharmacy records of medication } & \multicolumn{6}{|c|}{$\begin{array}{l}\text { Comparison of non-adherence results obtained with the } \\
\text { questionnaire vs. prescription records }\end{array}$} \\
\hline & & \multirow{2}{*}{\multicolumn{2}{|c|}{\begin{tabular}{l|l} 
Questionnaire & \\
\end{tabular}}} & \multicolumn{4}{|c|}{ Prescription records? } \\
\hline & & & & \multicolumn{2}{|c|}{$\begin{array}{c}<90 \% \\
\text { nonadherent }\end{array}$} & \multicolumn{2}{|c|}{\begin{tabular}{|c|}
$<80 \%$ \\
nonadherent \\
\end{tabular}} \\
\hline & & \multirow{2}{*}{\multicolumn{2}{|c|}{$\begin{array}{l}\text { Nonadherence } \\
\text { Adherence }\end{array}$}} & \multirow{2}{*}{\multicolumn{2}{|c|}{$\frac{25(10.3 \%)}{104(43 \%)}$}} & \multicolumn{2}{|c|}{$21(8.7 \%)$} \\
\hline & & & & & & \multicolumn{2}{|c|}{$62(25.6 \%)$} \\
\hline & & & \multicolumn{2}{|c|}{$\begin{array}{c}104(43 \%) \\
129(53.3 \%)\end{array}$} & \begin{tabular}{l|r|} 
& 831 \\
\end{tabular} & $34.3 \%)$ \\
\hline \multirow{4}{*}{$\begin{array}{l}\text { Martín MT et al. }{ }^{31} \\
\text { Design: Observational cross-sectional study. } \\
\text { Setting: Ambulatory pharmacy unit (hospital) } \\
\text { Study Population: HIV patients treated with HAART } \\
\text { Number of Subjects at Inclusion: } 1936 \\
\text { Objective: To assess the relationship between } \\
\text { adverse reactions (AR) and non-adherence to HAART } \\
\text { treatment. }\end{array}$} & \multirow{4}{*}{$\begin{array}{l}\text { - Pill count. } \\
\text { - Pharmacy records of medication refill (if pill count was unavailabl } \\
\text { Patients were considered adherent if they took } \geq 90 \% \text { of the prescrib } \\
\text { doses. }\end{array}$} & \multicolumn{6}{|c|}{$\begin{array}{l}33 \% \text { of subjects were nonadherent. Relationship between } \\
\text { occurrences of AR and adherence was as follows: }\end{array}$} \\
\hline & & & \multicolumn{2}{|c|}{$\begin{array}{l}\text { Patients (\%) } \\
\text { with } \\
\text { medication } \\
\text { adherence < } \\
90 \%\end{array}$} & \multicolumn{2}{|c|}{$\begin{array}{l}\text { Patients (\%) } \\
\text { with } \\
\text { medication } \\
\text { adherence } \geq \\
90 \%\end{array}$} & $\begin{array}{c}P \\
\text { value }\end{array}$ \\
\hline & & w/o AR & \multicolumn{2}{|c|}{$30 \%$} & \multicolumn{2}{|c|}{$70 \%$} & \multirow{2}{*}{0.007} \\
\hline & & With AR & 38 & & & $62 \%$ & \\
\hline $\begin{array}{l}\text { Martín-Sanchez et al. } \\
\text { Design: Cross-sectional study. } \\
\text { Setting: HIV outpatient clinics. } \\
\text { Study Population: HIV infected patients treated with } \\
\text { HAART. } \\
\text { Number of Subjects at Inclusion: } 206 \\
\text { Objective: To determine adherence to HAART and } \\
\text { the associated variables. }\end{array}$ & $\begin{array}{l}\text { - Clinical interview: Doses missed in the } 4 \text { days prior to the interview. } \\
\text { Patients were considered nonadherent if they took }<90 \% \text { of the total } \\
\text { prescribed dose of at least one drug. } \\
\text { - Medication refill: Delay in collection of prescribed drugs from the } \\
\text { hospital pharmacy over the previous } 3 \text { months. Patients were } \\
\text { considered nonadherent when they reached a cumulative delay of } \\
\text { more than } 9 \text { days. } \\
\text { - Variables: clinical information, sociodemographic information, risk } \\
\text { factors for HIV infection, adverse effects, self beliefs and TARGA self- } \\
\text { perceived effectiveness, alcohol and recreational drugs consumption, } \\
\text { symptoms of depression in the last week, and capability for self- } \\
\text { control in the last month. }\end{array}$ & \multicolumn{6}{|c|}{$\begin{array}{l}\text { - Total non-adherent patients: } 108 / 206(52.4 \% ;[95 \% \mathrm{Cl} 45.6: 59.2] \\
\text { Clinical interview: } 44 / 206(21.4 \% ;[95 \% \mathrm{Cl} 15.8: 27] \\
\text { Medication refill: } 89 / 206(43.2 \% ;[95 \% \mathrm{Cl} 36.4: 50.0] \\
\text { - Poor treatment adherence associated variables }(\mathrm{p}<0.01) \text { were: } \\
\text { Cocaine consumption (adjusted OR 5.1) } \\
\text { Self-reported effectiveness (adjusted OR 2.5) } \\
\text { Not being prescribed a Zidovudine-Lamivudine combination } \\
\text { (adjusted OR 1.9) }\end{array}$} \\
\hline
\end{tabular}




\begin{tabular}{|c|c|c|c|c|}
\hline Study Characteristics & Adherence Measurement Methods & \multicolumn{3}{|c|}{ Study Outcomes } \\
\hline $\begin{array}{l}\text { Méndez Lora M et al. }{ }^{34} \\
\text { Design: Observational cross-sectional study. } \\
\text { Setting: Community pharmacies } \\
\text { Study Population: Patients with hypertension. } \\
\text { Number of Subjects at Inclusion: } 400 \\
\text { Objective: To describe adherence to hypertension } \\
\text { treatment and its determining factors in the ASE } \\
\text { model (attitude, social influence and self-reported } \\
\text { efficacy) in order to learn which factors best explain } \\
\text { adherence behavior. }\end{array}$ & $\begin{array}{l}\text { Validated questionnaire to evaluate adherence in hypertensive patients } \\
\text { and associated psycho-social factors. It combines a number of } \\
\text { instruments: Batalla, Morisky-Green, Haynes and Sackett, ASE model } \\
\text { variables, Prochaska and DiClemente stages of change variables. }\end{array}$ & \multicolumn{3}{|c|}{$\begin{array}{l}\text { Adherent subjects (\%) according to each method: } \\
\text { - Batalla Test: } 50 \% \text {. } \\
\text { - Haynes Test: } 77 \% \text {. } \\
\text { - Morisky-Green Test: } 63 \% \text {. } \\
\text { - Self-reported medication adherence: } 97 \% \text {. } \\
\text { - Self-reported pills missed method: } 90 \% \text {. } \\
\text { - Self-reported pills taken: } 85 \% \text {. } \\
\text { - Prochaska and DiClemente: } 92 \% \text {. } \\
\text { - Correlation to direct questions answered by the patient regarding } \\
\text { medication adherence: } 78 \% \text {. }\end{array}$} \\
\hline $\begin{array}{l}\text { Morillo Verdugo R et al. }{ }^{32} \\
\text { Design: retrospective. } \\
\text { Setting: Hospital. Pharmacy service } \\
\text { Study Population: Patients treated with Abacavir, } \\
\text { Lamivudine and Zidovudine (ABC-3TC-AZT) } \\
\text { Number of Subjects at Inclusion: } 114 \text { outpatients. } \\
\text { Objective: To identify causes of discontinued } \\
\text { antiretroviral treatment with simplified therapeutic } \\
\text { regimen ABC-3TC-AZT in hospital patients. }\end{array}$ & $\begin{array}{l}\text { - Multi-interval dispensing adherence: Pharmacy records of } \\
\text { medication refill. This indicator is calculated as: number of days of } \\
\text { medication dispensed/total number of days observed. Patient was } \\
\text { considered adherent when this indicator was greater than } 95 \% \text {. }\end{array}$ & \multicolumn{3}{|c|}{ 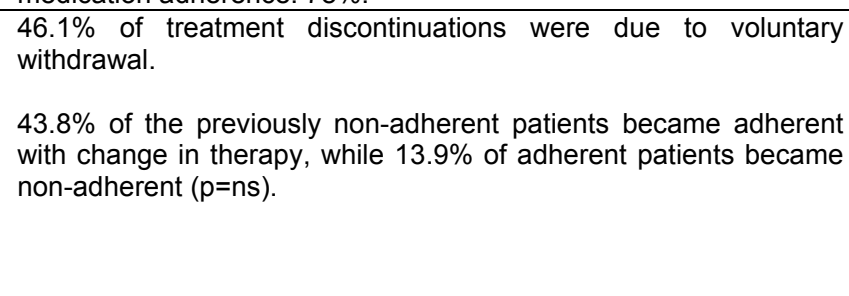 } \\
\hline \multirow{5}{*}{$\begin{array}{l}\text { Ventura-Cerdá JM et al. } \\
\text { Design: Observational cross-sectional study. } \\
\text { Setting: Hospital. Pharmacy Service } \\
\text { Study Population: HIV-infected patients. } \\
\text { Number of Subjects at Inclusion: } 63 \\
\text { Objective: To describe a simplified scale that can } \\
\text { measure adherence problems (Spanish ESPA) with } \\
\text { antiretroviral treatment and compare it to other } \\
\text { methods commonly used in clinical practice. }\end{array}$} & \multirow{5}{*}{$\begin{array}{l}\text { - Spanish scale ESPA [Escala Simplificada para Detectar Problemas } \\
\text { de Adherencia], used to measure adherence problems with } \\
\text { antiretroviral treatment, compared with: (1) medication refill (cutoff } \\
\text { point between adherent and nonadherent patients was defined at } \\
95 \% \text { ), and (2) Questionnaire developed by Gao \& Nau,, which } \\
\text { included four-item Morisky type scale and a continuous adherence } \\
\text { measure based on the percentage of doses taken as prescribed in } \\
\text { the } 2 \text { wks prior to the interview. Cutoff point here was also set at } 95 \% \\
\text { between adherent and nonadherent patients. }\end{array}$} & method & $\begin{array}{c}\% \text { of nonadherent } \\
\text { patients }\end{array}$ & \\
\hline & & ESPA & 60.3 & \\
\hline & & Prescription records & 47.6 & \\
\hline & & Morisky-Green type scale & 61.0 & \\
\hline & & Continuous measurement & 14.6 & \\
\hline \multicolumn{5}{|c|}{$\begin{array}{l}\text { NOM refers to a health problem or an undesirable health state in the patient attributed to the use (or non-use) of medications. In the article it appears as Medication-Related Problem (MRP) which is } \\
\text { the older nomenclature. In the new nomenclature the MRP becomes an NOR. }{ }^{56} \\
\text { b Questionnaire was validated by the same author in a prior study }{ }^{57} \\
{ }^{c} \text { Discontinuation does not directly correspond to nonadherence; rather a patient is said to have discontinued treatment if there was a change in therapy, when the patient missed two or more } \\
\text { consecutive clinical checkups, or when the pharmacy did not dispense the medication during more than three months. } \\
{ }^{2} \text { Gao X, Nau DP questionnaire. }\end{array}$} \\
\hline
\end{tabular}

